\title{
THAYER'S
}

\section{LIFE OF BEETHOVEN}

\author{
VOLUME I
}





\section{THAYER'S}

LIFE OF

\section{BEETHOVEN}

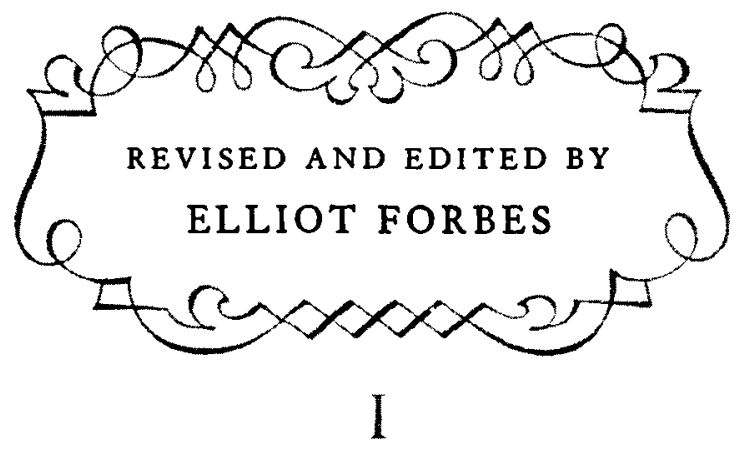

PRINCETON, NEW JERSEY

PRINCETON UNIVERSITY PRESS

1967 
Copyright 1921 by Henry Edward Krehbiel

Copyright renewed 1949 by Helen Krehbiel

Copyright assigned to Princeton University Press, 1949

Copyright (C) 5664,3967 by Princeton University Press

Revised Edition, 1967

ALL RIGHTS RESERVED

LC Card 66-29831

ISBN $0-691-09103-x$

ISBN $0-691-02717-x$ (pbk.)

978-0691-02717-3 $\diamond$

Cover photograph by Christian Steiner for Stereo Review

Copyright $\mathbb{C} 1969$ by Ziff-Davis Publishing Company

First Princeton Paperback Printing, 1970

Third Printing, 1973

Ninth Printing, 1989

Tenth paperback printing, for the first time in two volumes, 1991

$\begin{array}{lllll}19 & 18 & 17 & 16 & 15\end{array}$

Princeton University Press books are printed on acid-free paper, and meet the guidelines for permanence and durability of the Committee on Production Guidelines for Book

Longevity of the Council on Library Resources.

http:// pup.princeton.edu

Printed in the United States of America

ISBN-13: 978-0-691-02717-3 (pbk.) 